\title{
EXCESS CARRIER DECAY PECULIARITIES CAUSED BY DISORDER IN DISLOCATION-RICH SiGe AND GaN LAYERED STRUCTURES
}

\author{
E. Gaubas, A. Aleknavičius, M. Bauža, and A. Uleckas \\ Institute of Materials Science and Applied Research, Vilnius University, Sauletekio 10, LT-10223 Vilnius, Lithuania \\ E-mail: eugenijus.gaubas@ff.vu.lt
}

Received 7 July 2005

\begin{abstract}
Variations of the excess carrier transients under ultraviolet short-pulse excitation have been examined in dislocation-rich strain-relaxed SiGe and semi-insulating GaN layered structures. These characteristics were measured by microwave probe techniques. Peculiarities of recombination assisted by trapping processes were revealed. Parameters of the disordered structures attributed to dislocation networks were determined. Generalized features of dislocation-rich layers caused by fractal structure of extended defect networks are discussed.
\end{abstract}

Keywords: recombination and trapping, strain-relaxed SiGe layers, semi-insulating GaN, microwave absorption transients

PACS: $61.43 . \mathrm{Hv}, 61.72 . \mathrm{Hh}, 61.82 . \mathrm{Fk}, 72.40 .+\mathrm{w}$

\section{Introduction}

Recombination transients provide direct information on the carrier lifetime, which is one of the crucial indicators of the materials quality. In a dislocation-rich material, such as layers of the strained silicon (SSi) on a strain-relaxed SiGe buffer (SRB) fabricated for enhancement of carrier mobility, the dislocation networks may cause a disordered structure [1] with specific carrier trapping and asymmetric diffusion properties. However, a role of the threading, misfit, and pile-up dislocations in SSi-SiGe SRB structures is not clear enough. Determination of the carrier recombination and transport features in the dislocation-rich materials is important in order to predict the integral electrical characteristics of devices fabricated in the SRB substrates. In semi-insulating (SI) GaN epitaxial layers, the decays of excess carriers in a time span ranging from sub-nanoseconds to seconds are intricate and consist of an initial quasi-exponential recombination followed by a power-law relaxation in the asymptotic part [2]. Under the high excitation conditions, the initial recombination dynamics of non-equilibrium electron-hole plasma population in GaN films is essentially non-exponential [3]. Evaluation of recombination parameters in the asymptotic part of relaxation is also complicated due to the multi-trapping processes $[4,5]$. In dislocation-rich $\mathrm{GaN}$, a consistent transition from the processes dominated by elementary recombi- nation events to the disorder-inherent phenomena with evolution of the excess carrier concentration is not well described yet. Understanding of these processes is important for establishing a set of the main parameters for evaluation of the quality of materials by relating the transient process parameters to the defect concentrations and peculiarities of their distribution and occupation. Comparison of different materials, such as the $\mathrm{SSi}-\mathrm{SiGe} \mathrm{SRBs}$ and GaN layered structures containing dislocations in the same density range, is relevant to reveal the general features of dislocation-caused peculiarities of carrier recombination and transport due to disorder. Moreover, specialized methods should be employed to examine the properties of ultra-thin layers residing on the top of multi-layered structures and to resolve the parameters of these layers on the background of substrate.

In this article, the correlated investigations of the transient contact photoconductivity (CPC) and microwave absorption (MWA) are presented and analyzed in order to identify the peculiarities attributed to disordered dislocation networks in the epitaxial $\mathrm{GaN}$ and $\mathrm{SSi}-\mathrm{SiGe}$ SRB layers. The redistribution of free-carrier capture fluxes between the recombination and multitrapping centres was examined and the behaviour of the capture centres attributed to dislocations was evaluated. 


\section{Samples}

Semi-insulating GaN films of $2 \mu \mathrm{m}$ thickness were examined. The epi-layers were grown by metalorganic chemical vapour deposition (MOCVD) on sapphire substrates using a $2 \mu \mathrm{m}$ thick $n$-GaN buffer layer. The epilayer growth was performed at enhanced trimethylgallium flow rates. The epilayers of these samples contain columnar structure as revealed by the TEM observations [6]. The densities of threading dislocations were estimated to be in the range of $10^{8}-10^{10} \mathrm{~cm}^{-2}$. Few samples had electrical contacts deposited on the epilayer surface. The ohmic contacts were fabricated using a $\mathrm{Ti} / \mathrm{Al}$ metallization. In the contact photoconductivity experiments, the sample was biased between laterally deposited contacts.

The second set of samples consisted of as-grown SSi wafers, with a $420 \mathrm{~nm}$ thick SRB layer [1], containing different dislocation densities. The emission microscopy (EMMI) images shown in the insets 1 and 2 of Fig. 1(a) exhibit the dislocation networks in SRB layer and reference $\mathrm{Si}$ substrate, respectively. This implies the formation of a disordered structure of the fractal type in SRB layer, in contrast to the Si substrate, representing a perfect Si crystal [1]. Moreover, the threading and misfit dislocations can be recognized only as minute details in the SRB EMMI images showing mainly the macroscopic nets. The characteristic densities of threading dislocations (TD) in the range of $2 \cdot 10^{6}-10^{9} \mathrm{~cm}^{-2}$ and more, pile-up dislocations in the range of $200-2000 \mathrm{~cm}^{-1}$, and misfit dislocations of about 100 were derived from the micrographs after preferential etching in as-grown SRB layers.

\section{Experimental techniques}

The measurements of the recombination characteristics were performed by microwave absorption / reflection (MWA/R) techniques combined with contact photoconductivity (CPC) for $30 \mathrm{ps}$ and $10 \mathrm{~ns}$ photoexcitation pulses of $\mathrm{UV}$ radiation of the 3rd harmonic of YAG: $\mathrm{Nd}^{3+}$ lasers. The MWA/R technique is based on the pump-probe measurement mode where the probe is due to the microwave absorption by free carriers. This method allows avoiding the contact effects and provides one with a simple insight into the temperature variations of recombination characteristics. Moreover, the application of the excitation pulses of different duration allows monitoring of the rise of photoresponse. The CPC technique was implemented by measuring the photocurrent decays. In both the MWA/R and CPC experiments, the variation of the excess carrier decay rate has been determined over a wide time scale ranging from $5-100 \mathrm{~ns}$ to $0.5-20 \mathrm{~ms}$ in GaN epi-layers and from $3-900 \mathrm{~ns}$ to $>50 \mu \mathrm{s}$ in SSi-SiGe SRB structures, respectively.

To reveal the differences in the recombination behaviour between the GaN epilayer and $n$-GaN substrate as well as between the SSi-SiGe SRB and Si substrates, the MWA decays were examined by comparing the results obtained by excitation of either a face layer or a substrate side of the structure. For the steady-state trap filling/emptying, an additional bias illumination of variable wavelength was exploited by using cw radiation of either $\mathrm{Ar}^{+}$laser or incandescent lamp.

Variations of excess carrier relaxation in wide time scale were examined by varying the pulsed excitation density. Also, the temperature dependences of the initial and asymptotic decay lifetimes were controlled in GaN layers by the MWA.

\section{Results and discussion}

The MWA transients recorded in the $\mathrm{SSi} / \mathrm{SiGe}$ $\mathrm{SRB} / \mathrm{Si}$ structures at the same 30 ps pulsed excitation intensity are presented in Fig. 1(a) for the sample with TD density of $10^{7} \mathrm{~cm}^{-2}$, including the decays obtained for the rough Si substrate surface (curve 1) and mirrorlike top SRB layer (curve 2). The decay shape and rate clearly differs for SRB and Si surfaces. The MWR transient registered on bare $\mathrm{Si}$ exhibits a one-exponential carrier decay, and this can be explained by the dominance of bulk recombination in $\mathrm{Si}$ when the surface states are suppressed by filling with a high carrier density in the initial excitation domain. Also, the effective recombination lifetime in bare $\mathrm{Si}$ is shorter than that measured for SRB layers in the asymptotic limit, as seen from comparison of curves 1 and 2 at nearly the same experimental conditions. The small initial component can be explained by considering that the excess carrier density caused a modulation of the Debye length of the surface states on bare Si. However, the MWA transient integrated over the SRB layers acquires a hyperbolic shape. At slow diffusion in the disordered SRB structure identified by the reflection transients [7] the excess carrier decay is most probable via local recombination processes. The appearance of the twocomponent decays in a broad range of carrier concentrations measured in MWA/MWR transients implies the competition of the direct carrier recombination and the multi-trapping processes. In the case of competing recombination and trapping processes, the excess 
carrier decay can be characterized by an instantaneous lifetime $\tau_{\text {inst }}$, representing a mixture of recombination $\tau_{\mathrm{R} \infty}$ and trapping $\tau_{\mathrm{tr}}$ lifetimes. The differential relation between these lifetimes can be expressed through a trapping coefficient $K_{\mathrm{tr}}$, which is a function of $\tau_{\mathrm{tr}}$ as $\tau_{\text {inst }}=\tau_{\mathrm{R} \infty} K_{t r}\left(\tau_{\text {tr }}\right)$. A simplified estimation of $K_{\text {tr }}$ can be made graphically by extrapolating $\tau_{\mathrm{R} \infty}$ and taking the ratio $\tau_{\text {inst }} / \tau_{\mathrm{R} \infty}$. The so extracted $K_{\mathrm{tr}}$ values appeared to be rather large, $K_{\mathrm{tr}}>10$, in the intermediate decay stages. In the GaN epilayers, the excess carrier decays recorded by MWA and CPC techniques are compared in Fig. 1(b), and these nearly coinciding decays stretch for tens of ms. The relaxation stretching implies that the carrier multi-capture and trap filling effects play the main role in the asymptotic decay part. The initial decay part is more intricate, containing the fast component of a few ns that evolves into a slower hyperbolic-like decay, as in $\mathrm{SSi} / \mathrm{SiGe} \mathrm{SRB} / \mathrm{Si}$ structures.

The effective initial and asymptotic decay lifetimes and the relative amplitudes of these decay components vary in the $\mathrm{SSi} / \mathrm{SiGe} \mathrm{SRB} / \mathrm{Si}$ structures with excitation intensity, as shown in Fig. 2(a). However, the effective decay rate in the Si substrate is nearly independent of the UV excitation intensity in the same excitation density range. In contrast, the initial decay lifetime for the SRB layer decreases with excitation intensity, but the relative amplitude of the asymptotic decay grows with excitation density and the effective lifetime becomes longer (curves 3 to 1 of Fig. 2(a)). Qualitatively the same variations induced by the excitation intensity were obtained in the SRB layers having different TD densities in the range of $10^{7}-10^{9} \mathrm{~cm}^{-2}$. However, the absolute values of the effective lifetimes slightly increase with the TD density at the same excitation intensity, while the transients for the Si substrate side almost coincide. These dependences can be explained by the peculiarities of trapping within the space charge region surrounding the dislocation. As the free electrons and trapped holes are separated in space, the direct recombination at the dislocation space charge boundary is improbable. However, the carrier capture time is short and the capture process participates in a redistribution of the direct recombination flux at the initial carrier decay stages. Conventional models of potential barriers at dislocations and of trappingrecombination processes imply the formation of a trapping well with a cross-section dependent on the excess carrier density. Since the capture cross-section and activation energy of these traps depend on their occupation and vary during the relaxation of the excess car-

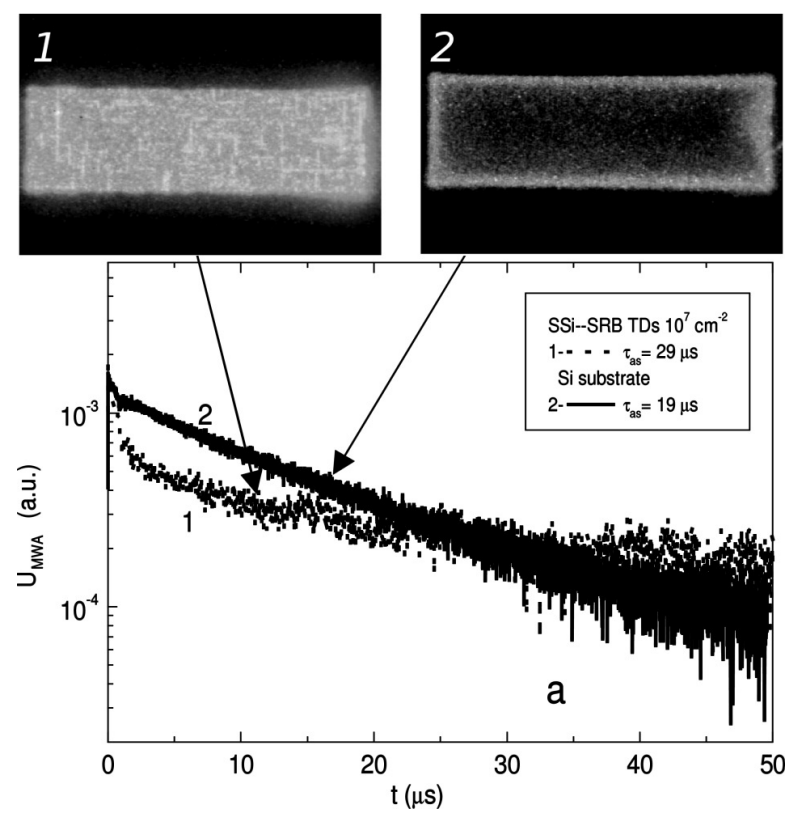

(a)

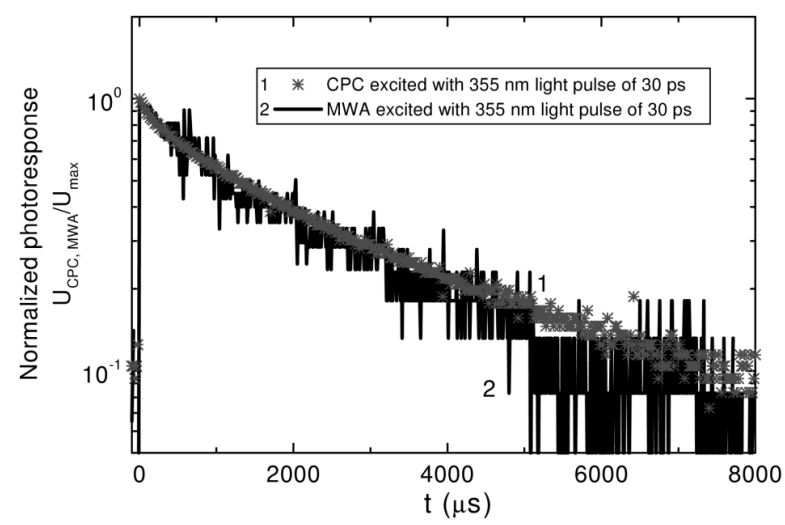

(b)

Fig. 1. (a) MWA asymptotic relaxation in the SRB layer (1) is compared with that in the Si substrate (2) of the SSi / SiGe SRB / Si structure. (b) The CPC (1) and MWA (2) transients obtained in GaN epilayer. Insets 1 and 2 of (a) illustrate EMMI micrographs corresponding to wafer fragments with dislocation network in the SRB layer and reference Si substrate of the perfect crystalline structure, respectively.

riers, the distribution of the trap depth in a dislocation cluster is random.

The hyperbolic-like decay character and increase of the trapping component with excitation density are also inherent for GaN epilayers, as shown in Fig. 2(b) for the intermediate time interval. An increase of the trapping component with excitation intensity implies the carrier density dependent capture rates. In the CPC and MWA transients, the intermediate decay interval is narrowing with excitation intensity, and a saturation occurs (Fig. 2(b)). This saturation effect, which depends on the defect structure and concentration, is more pronounced in MWA decays measured for GaN 


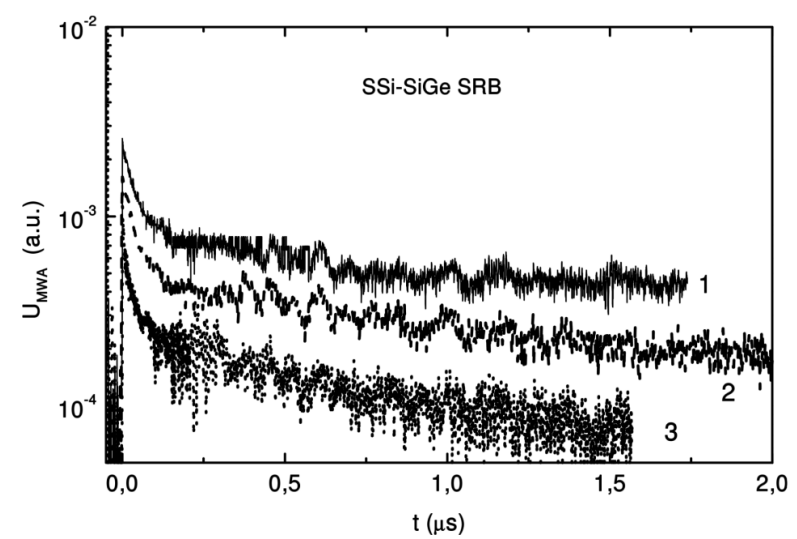

(a)

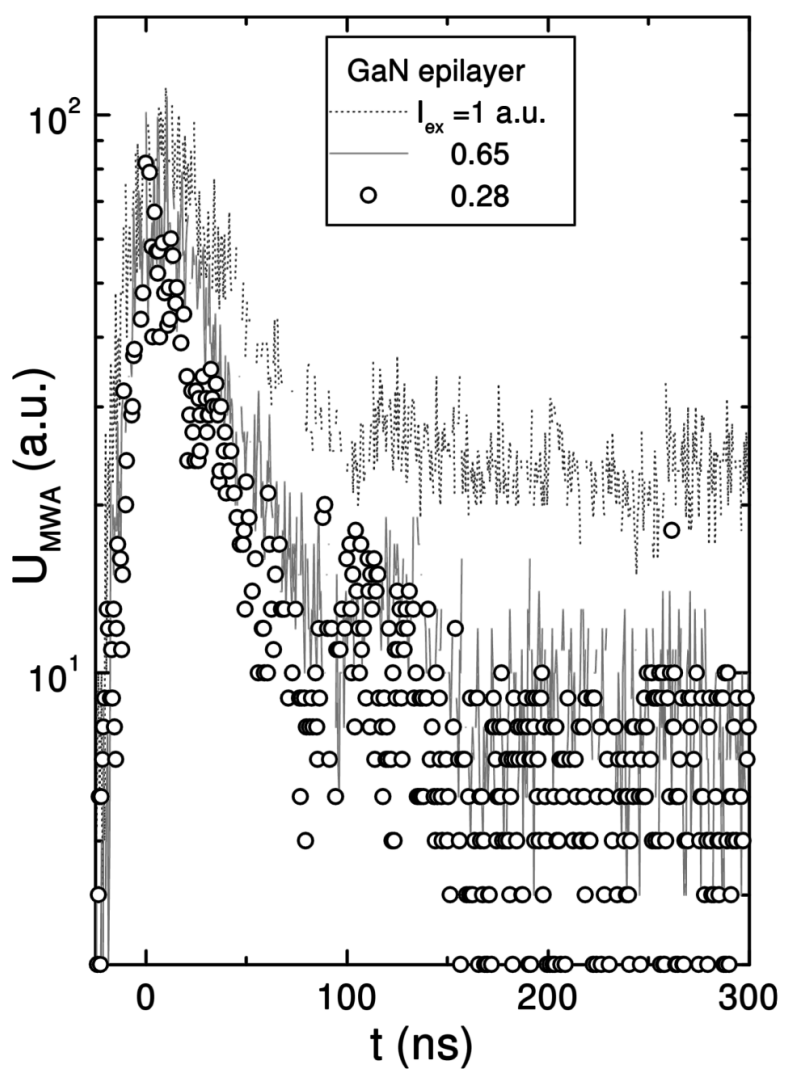

(b)

Fig. 2. Excitation intensity dependent MWA transients measured exploiting the UV pulsed radiation when (a) the SSi-SiGe SRB and (b) the GaN layer is excited. The relative excitation intensities in (a): 1 for $4.5 I_{0}, 2$ for $3.5 I_{0}, 3$ for $2 I_{0}$.

by exciting the excess carriers in the substrate side of the structure with a larger density of defects. Such a phenomenon is again probable when the capture crosssection varies with trap filling. However, additional cw bias illumination of different wavelengths resulted in neither observable decay rate changes nor quenching effects. The temperature dependences of the instantaneous decay lifetimes were additionally recorded by MWA technique in the initial and the asymptotic part of the transients. Irrespectively of the time intervals examined, the activation energy was found to exhibit a remarkable persistence in activation energy of $0.3 \mathrm{eV}$. The derived activation energy is in a good agreement with those for the dislocation-rich GaN materials. The activation factor of $0.3 \mathrm{eV}$, extracted from the temperature dependences of instantaneous lifetimes, seems to be due to a modulation of the barriers associated with the acceptor band in dislocation-rich GaN. The persistence of activation factor is also inherent for disorderattributed carrier motion.

To account for the asymptotic decay, the local decay lifetimes should be statistically generalized for the competing recombination and trapping centres with a dispersion of parameters (the recombination lifetime $\tau_{\mathrm{R} \infty}$, the capture time, and the release time). In the SSi SRB and epi-GaN layers, a non-uniform distribution of extended defects was identified from emission (inset 1 ) and transmission microscopy images. The increase of the asymptotic decay time with dislocation density was determined in the SSi SRB layers, and this implies the disorder-caused trapping enhancement with the dislocation density in these SRB structures. Generally, the analysis of non-equilibrium carrier dynamics in such an inhomogeneous structure leads to a macroscopic approach in terms of the stretched exponent relaxation [8].

Figure 3 shows the asymptotic part of the MWA decays in the stretched exponent representation $U_{\text {MWA,CPC }} \propto \exp \left[-\left(t / \tau_{\text {str }}\right)^{\beta}\right]$. The variation of the MWA photoresponse in the logarithmic scale is seen to be an almost linear function of $t^{\beta}$. However, the linearization of the asymptotic relaxation was at $\beta \approx 0.15$ for SSi SRB structures (Fig. 3(a)), while the stretching factor was found to be $\beta \approx 0.70$ for GaN epi-layers (Fig. 3(b)). Also, the linearity of the asymptotic relaxation in the stretched exponent layout appears at the same factor $\beta$ for the samples with different TD densities in the SSi SRB structures. However, the characteristic stretched exponent lifetimes $\tau_{\text {str }}$ are found to be slightly different and increasing with the dislocation density. This confirms that the free carrier multitrapping, which is equivalent to the continuous-time random walk (CTRW) with fractal features $[9,10]$, is the main process that determines the asymptotic stage of relaxation at reduced carrier densities. The multitrapping disperses the direct recombination events in time, thus affecting the efficiency of direct recombination.

The determined stretched exponent factor $\beta$ allows one to roughly approximate the fractal dimension index 


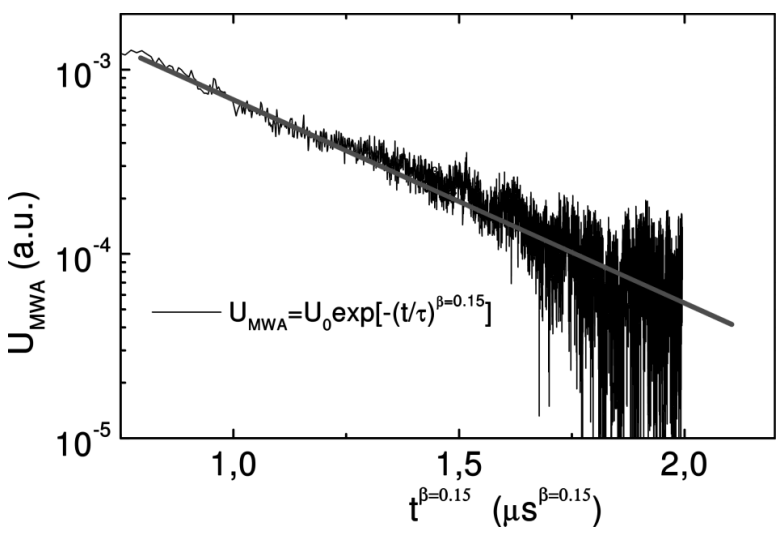

(a)

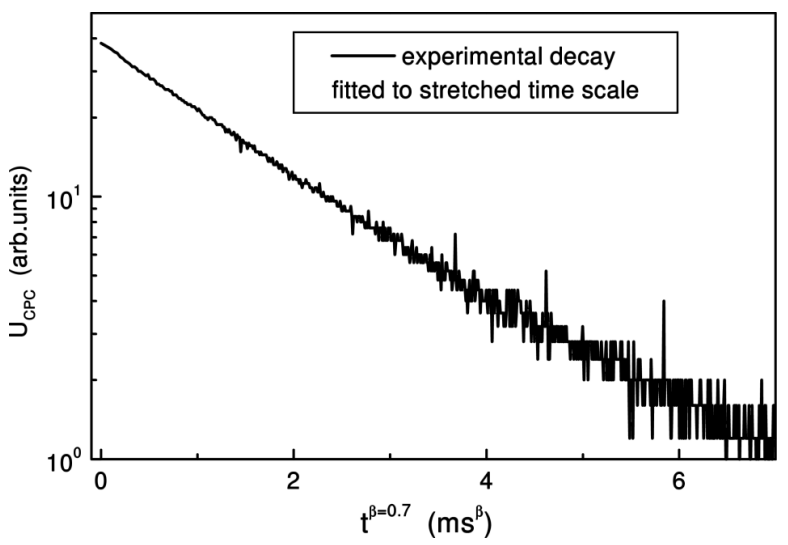

(b)

Fig. 3. (a) MWA decay plotted in the stretched exponent layout with time stretching factor $\beta=0.15$ for the SSi SRB sample, and (b) CPC decay plotted with time stretching factor $\beta=0.7$ for the SI GaN epilayer.

by $d_{\mathrm{s}}=2 \beta /(1-\beta)$. This index can be a characteristic of the disorder fractons for the carrier motion. The values of this index, estimated from the MWA asymptotic decays, were found to be $d_{\mathrm{s}}=0.35$ for the SSi SRB structures and $d_{\mathrm{s}}=4.6$ for the epi-GaN. This implies that a three-dimensional carrier motion dominates in the columnar network of crystallites structure of the GaN layers, while a random walk is more restricted in the space of chaotic disorder of TD and misfit dislocations in the SSi SRB structures.

\section{Conclusions}

A hyperbolic-like relaxation of the asymptotic carrier decay part was revealed in the dislocation-rich SSi-SiGe SRBs and GaN materials. This excitation density dependent relaxation was ascribed to trapping processes and characterized by trapping coefficients $K_{\mathrm{tr}}>10$. The values of the carrier diffusion coefficient $D_{a} \leq 0.13 \mathrm{~cm}^{2} / \mathrm{s}$ in the $\mathrm{SSi}-\mathrm{SiGe} \mathrm{SRB}$ structures corroborate the carrier transport limitations in- duced by disorder. The asymptotic multi-trapping process in the disordered structure of the dislocation-rich $\mathrm{SSi}-\mathrm{SiGe} \mathrm{SRB}$ s and GaN epilayers was generalized by the stretched exponent approach with a time-stretching index of about 0.15 for the SSi-SiGe SRB structures and of 0.7 in GaN layers, respectively. By employing these values of the time-stretching index, the fractal spectral dimension was estimated and found to be significantly less than the geometrical one in chaotic dislocations network of SSi-SiGe SRB layers, while $d_{\mathrm{s}}=4.6$ was evaluated for the epi-GaN containing a columnar structure.

\section{Acknowledgement}

G. Eneman, R. Delhougne, and E. Simoen are acknowledged for the provided SSi SRB wafers and their qualitative characteristics.

\section{References}

[1] G. Eneman, E. Simoen, A. Lauwers, R. Lindsay, P. Verheyen, R. Delhougne, R. Loo, M. Caymax, P. Meunier-Beillard, S. Demuynck, K. De Meyer, and W. Vandervorst, Analysis of junctions formed in strained $\mathrm{Si} / \mathrm{SiGe}$ substrates, MRS Proc. 809, 187 (2004).

[2] Ch. Qiu, W. Melton, M.W. Leksono, J.I. Pankove, B.P. Keller, and S.P. DenBaars, Photocurrent decay in $n$-type GaN thin films, Appl. Phys. Lett. 69, 1282 (1996).

[3] A. Dmitriev and A. Oruzheinikov, The rate of radiative recombination in the nitride semiconductors and alloys, J. Appl. Phys. 86, 3241 (1999).

[4] E. Gaubas, K. Kazlauskas, R. Tomašiūnas, J. Vaitkus, and A. Žukauskas, Radiation-defect-dependent photoconductivity transients and photoluminescence in semi-insulating GaN, Appl. Phys. Lett. 84, 5258 (2004).

[5] E. Gaubas, S. Juršėnas, S. Miasojedovas, J. Vaitkus, and A. Žukauskas, Carrier and defect dynamics in photoexcited semi-insulating epitaxial GaN layers, J. Appl. Phys. 96, 4326 (2004).

[6] J. Bai, T. Wang, Y. Izumi, and S. Sakai, A study of dislocations in InGTaN/GaN multiple-quantum-well structure grown on (1120) sapphire substrate, J. Cryst. Growth 223, 61 (2001).

[7] E. Gaubas, A. Uleckas, and E. Simoen, Excess carriers dynamics in SiGe ultra-thin layers, Lithuanian J. Phys. 45, 377 (2005).

[8] L. Pavesi and M. Ceschini, Stretched-exponential decay of luminescence in porous silicon, Phys. Rev. B 48, 17625 (1993). 
[9] G. Pfister and H. Sher, Dispersive (non-Gaussian) transient transport in disordered solids, Adv. Phys. 27, 747 (1978).
[10] S. Havlin and D. Ben-Avraham, Diffusion in disordered media, Adv. Phys. 51, 187 (2002).

\title{
NETVARKOS LEMIAMI NEPUSIAUSVIRŲJU KRŪVININKŲ RELAKSACIJOS YPATUMAI DIDELIO DISLOKACIJŲ TANKIO SiGe ir GaN SLUOKSNIUOTUOSE DARINIUOSE
}

\author{
E. Gaubas, A. Aleknavičius, M. Bauža, A. Uleckas \\ Vilniaus universiteto Medžiagotyros ir taikomuju mokslu institutas, Vilnius, Lietuva
}

\section{Santrauka}

Ištirti didelio dislokacijų tankio $\left(10^{6}-10^{10} \mathrm{~cm}^{-2}\right) \mathrm{SiGe}$ ir GaN sluoksniniai dariniai, siekiant atskleisti rekombinacijos ir krūvininku prilipimo reiškiniu ypatumus ir i̇vertinti vyksmu parametrus, lemiančius $\mathrm{SiGe}$ ir $\mathrm{GaN}$ darinių elektrines savybes. Atskleisti nepusiausviruju krūvininku tankio relaksacijos ypatumai, nulemti sparčios rekombinacijos ir laike ištęstu prilipimo vyksmu netvarkioje sandaroje. Tie ypatumai pasirodè esą bendri SSi-SiGe ir $\mathrm{GaN}$ didelio dislokacijų tankio dariniams. Ilgatrukmė kvazihiperbolinė relaksacija, būdinga tiek $\mathrm{SSi}-\mathrm{SiGe}$, tiek GaN dariniams, buvo aproksimuota ištęstos eksponentès modeliu. Buvo ìvertinti ištęstos eksponentès rodikliai $\beta$ ir rastos tokios jų vertės: $\beta=0,15$ SSi-SiGe ir $\beta=0,7 \mathrm{GaN} / n$-GaN dariniams. Tos vertès byloja apie fraktalinị kristalinès sandaros pobūdị. Skirtingi ištęstos eksponentės rodikliai $\mathrm{SSi} / \mathrm{SiGe}$ ir $\mathrm{GaN} / n-\mathrm{GaN}$ dariniams sietini su ivvairių orientacijų siūlinių bei sanklodos dislokacijų tinklo susidarymu nanometrinio storio $\mathrm{SSi}-\mathrm{SiGe}$ sluoksniuose, kai mikrometriniuose GaN sluoksniuose susidaro koloninés kristalitu, supamų siūlinių dislokacijų, sandaros. Aptariama rekombinacinių ir sandaros parametrų kitimų koreliacija bei krūvininku pernašos pobūdis tuose netvarkiuose dariniuose, siejant su fraktalų spektrine dimensija. 